\title{
MODEL PENDAMPINGAN UMKM BIDANG KERAJINAN MENJADI START-UP SUKSES DI KOTA MALANG
}

\author{
Mochammad Rofieq ${ }^{1)}$, Ditya Permatasari ${ }^{2)}$, Lailatul Farida ${ }^{3)}$ \\ ${ }^{1)}$ Fakultas Teknik Universitas Merdeka Malang \\ ${ }^{2,3)}$ Fakultas Ekonomi Universitas Islam Negeri Maliki Malang \\ email:mochammad.rofieq@unmer.ac.id
}

\begin{abstract}
Abstrak
Kota Malang memiliki 77.778 UMKM dan 141.906 pekerja di berbagai bidang usaha, salah satunya adalah kerajinan (Handicraft). UMKM Kota Malang dikenal memiliki produk yang bagus dan berkualitas, namun masih banyak dari UMKM tersebut yang masih harus berjuang dalam desain produk dan kemasannya, proses penjualan secara online untuk mengembangkan pasar, serta aspek akuntansi keuangannya. Selain itu akses permodalan juga menjadi kendala bagi UMKM bidang Kerajinan ini untuk bisa menjadi Start-Up yang sukses dalam menjalankan usahanya. Oleh karena itu diperlukan suatu model pendampingan yang tepat bagi UMKM bidang kerajinan ini sesuai dengan kebutuhan dan kemampuan para pelaku usahanya. Metode kegiatan pendampingan UMKM ini dilaksanakan dalam bentuk : Brainstorming, Focus Group Discussion, Seminar Kewirausahaan, Kuliah Tamu, berbagai macam Pelatihan, Workshop dan mengikuti berbagai kegiatan Expo / Pameran.
\end{abstract}

Kata Kunci : APKM, Kerajinan, Model, Pendampingan, UMKM

\section{PENDAHULUAN}

Pesatnya perkembangan UMKM dewasa ini seiring dengan perkembangan teknologi informasi membuat perekonomian di Indonesia terus meningkat. Hal ini sesuai dengan data dari Kementerian Koperasi dan Usaha Kecil dan Menengah (Kemenkop UKM) yang mentargetkan pertumbuhan UMKM baru sekitar $5 \%$ dari jumlah penduduk pada akhir 2019. Pendidikan yang berwawasan Knowledge Based Economy mendapat perhatian yang sangat besar dari pemerintah melalui berbagai program yang terkait dengan Kewirausahaan di Perguruan Tinggi, baik dari sisi kurikulum yang tercermin dari Mata Kuliah Kemandirian dan Kewirausahaan, maupun dalam kerangka pelaksanaan Tri Dharma Perguruan Tinggi yang ketiga, yakni Pengabdian kepada Masyarakat.

Kegiatan yang dimaksud antara lain dilaksanakan dalam bentuk Kuliah Kerja Nyata (KKN) tematik Kewirausahaan, Program Cooperative Academic Education, Diklat Kewirausahaan untuk dosen dan mahasiswa, serta pendampingan untuk para pelaku usaha skala kecil dan mikro melalui peran Lembaga Penelitian dan Pengabdian kepada Masyarakat (LPPM) Perguruan Tinggi Negeri dan Swasta. Bersama lembaga perbankan seperti Bank Indonesia, Perguruan Tinggi selain menghasilkan tenaga-tenaga terdidik formal yang memiliki soft skills Kewirausahaan, diharapkan juga mampu menjadi tenaga pendamping atau konsultan bagi UMKM dari segi manajerial dan segi pembiayaaan baik secara konvensional maupun secara syariah.

Tabel 1.

Jumlah UMKM dan Tenaga Kerja di Jawa Timur Tahun 2018

\begin{tabular}{|c|l|c|c|}
\hline \multirow{2}{*}{ NO } & \multirow{2}{*}{ KOTA / KABUPATEN } & \multicolumn{2}{|c|}{ JUMLAH } \\
\cline { 3 - 4 } & & UMKM & TENAGA KERJA \\
\hline 1 & Pacitan & 181.115 & 221.784 \\
\hline 2 & Ponorogo & 207.561 & 306.487 \\
\hline 3 & Trenggalek & 143.455 & 194.016 \\
\hline 4 & Tulungagung & 181.409 & 280.424 \\
\hline 5 & Blitar & 255.622 & 406.719 \\
\hline 6 & Kediri & 251.493 & 395.355 \\
\hline 7 & Malang & 414.516 & 826.375 \\
\hline 8 & Lumajang & 196.446 & 287.251 \\
\hline 9 & Jember & 424.151 & 729.962 \\
\hline 10 & Banyuwangi & 296.706 & 501.379 \\
\hline 11 & Bondowoso & 172.378 & 277.434 \\
\hline 12 & Situbondo & 156.727 & 263.547 \\
\hline 13 & Probolinggo & 235.286 & 397.327 \\
\hline 14 & Pasuruan & 248.802 & 403.965 \\
\hline 15 & Sidoarjo & 171.264 & 306.481 \\
\hline
\end{tabular}




\begin{tabular}{|c|l|c|c|}
\hline \multirow{2}{*}{ NO } & \multirow{2}{*}{ KOTA / KABUPATEN } & \multicolumn{2}{|c|}{ JUMLAH } \\
\cline { 3 - 4 } & & UMKM & TENAGA KERJA \\
\hline 16 & Mojokerto & 155.410 & 262.651 \\
\hline 17 & Jombang & 188.614 & 328.380 \\
\hline 18 & Nganjuk & 201.463 & 322.229 \\
\hline 19 & Madiun & 146.562 & 242.654 \\
\hline 20 & Magetan & 154.800 & 233.043 \\
\hline 21 & Ngawi & 185.312 & 309.653 \\
\hline 22 & Bojonegoro & 281.967 & 471.481 \\
\hline 23 & Tuban & 223.998 & 370.537 \\
\hline 24 & Lamongan & 252.734 & 421.825 \\
\hline 25 & Gresik & 168.393 & 239.182 \\
\hline 26 & Bangkalan & 166.768 & 210.003 \\
\hline 27 & Sampang & 195.215 & 264.569 \\
\hline 28 & Pamekasan & 195.554 & 257.481 \\
\hline 29 & Sumenep & 269.005 & 486.196 \\
\hline 30 & Kota Kediri & 29.306 & 51.039 \\
\hline 31 & Kota Blitar & 21.291 & 35.439 \\
\hline 32 & Kota Malang & 77.778 & 141.906 \\
\hline 33 & Kota Probolinggo & 26.125 & 41.120 \\
\hline 34 & Kota Pasuruan & 24.257 & 44.520 \\
\hline 35 & Kota Mojokerto & 17.480 & 31.212 \\
\hline 36 & Kota Madiun & 22.662 & 41.557 \\
\hline 37 & Kota Surabaya & 260.762 & 466.779 \\
\hline 38 & Kota Batu & 23.544 & 45.477 \\
\hline & JAWA TIMUR & 6.825 .931 & 11.117 .439 \\
\hline & & & \\
\hline
\end{tabular}

\section{Sumber : Dinas Koperasi dan UKM Jawa Timur (2018)}

Kota Malang memiliki 77.778 UMKM dan 141.906 pekerja di berbagai bidang usaha, salah satunya adalah kerajinan (Handicraft). UMKM Kota Malang dikenal memiliki produk yang bagus dan berkualitas, sehingga tidak mengherankan apabila pada saat dilaksanakan kegiatan Jatim Expo Tahun 2017 kota ini dinobatkan sebagai Kota Branding.

Namun masih banyak dari UMKM tersebut yang masih harus berjuang dalam desain produk dan kemasannya, proses penjualan secara online untuk mengembangkan pasar, serta aspek akuntansi keuangannya. Selain itu akses permodalan juga menjadi kendala bagi UMKM bidang Kerajinan ini untuk bisa menjadi Start-Up yang sukses dalam menjalankan usahanya. Oleh karena itu diperlukan suatu model pendampingan yang tepat bagi UMKM bidang kerajinan ini sesuai dengan kebutuhan dan kemampuan para pelaku usahanya.

\section{Identifikasi Permasalahan UMKM}

Identifikasi permasalahan yang dihadapi UMKM bidang kerajinan dilaksanakan melalui kegiatan brainstorming yang diikuti Lembaga
Penelitian dan Pengabdian kepada Masyarakat (LPPM) Universitas Merdeka Malang bersama para perajin Kota Malang yang tergabung dalam Asosiasi Perajin Kota Malang (APKM).

Tabel 2.

Rekapitulasi Permasalahan yang dihadapi oleh UMKM

\begin{tabular}{|c|c|}
\hline $\begin{array}{c}\text { Skala } \\
\text { Prioritas }\end{array}$ & Permasalahan \\
\hline Prioritas I & $\begin{array}{l}\text { 1. Desain Kemasan Produk } \\
\text { 2. Pemasaran Produk } \\
\text { 3. Website Pemasaran Online } \\
\text { 4. Katalog Produk }\end{array}$ \\
\hline Prioritas II & $\begin{array}{l}\text { 1. Aspek Legalitas } \\
\text { 2. Pembukuan } \\
\text { 3. PembuatanLaporan Pajak } \\
\text { 4. Space untuk Pemasaran Offline }\end{array}$ \\
\hline Prioritas III & $\begin{array}{l}\text { 1. Kekurangan Tenaga Kerja } \\
\text { 2. Teknologi Casting Kerajinan Perak } \\
\text { 3. Alat Produksi Pembuatan Mukena }\end{array}$ \\
\hline
\end{tabular}

Sumber : LPPM Universitas Merdeka Malang (2017)

Berdasarkan permasalahan yang terdapat dalam Tabel 2 tersebut dibuat suatu model pendampingan yang sesuai untuk Start-up UMKM Bidang Kerajinan di Kota Malang.

\section{METODE KEGIATAN}

Kegiatan yang dilaksanakan dalam membangun model pendampingan UMKM bidang kerajinan di Kota Malang menggunakan metode sinergi antara Perguruan Tinggi dalam hal ini Lembaga Penelitian dan Pengabdian kepada Masyarakat (LPPM) dengan Paguyuban Dosen Pengampu Mata Kuliah Kemandirian dan Kewirausahaan, Program Inkubator Bisnis Mahasiswa, Pelaku Usaha Bidang Kerajinan yang tergabung dalam Asosiasi Perajin Kota Malang (APKM), Pemerintah Daerah melalui Dinas terkait (Dinas Koperasi \& UKM, Dinas Perindustrian dan Perdagangan, Dinas Kebudayaan dan Pariwisata), Program Posdaya Wilayah Jawa Timur II, serta masyarakat pada umumnya.

Metode kegiatan pendampingan UMKM ini dilaksanakan dalam berbagai bentuk :

1. Brainstorming

2. Focus Group Discussion

3. Seminar Kewirausahaan

4. Kuliah Tamu

5. Pelatihan

6. Workshop

7. Expo / Pameran 


\section{HASIL DAN PEMBAHASAN}

\section{Seminar Kewirausahaan}

Sebagai penyelenggara kegiatan Seminar Kewirausahaan ini adalah Pusat Kewirausahaan, Kemandirian dan Inkubator Lembaga Penelitian dan Pengabdian kepada Masyarakat (LPPM) Universitas Merdeka Malang yang bekerjasama dengan Koordinator Program Posdaya Wilayah Jawa Timur II dan Asosiasi Perajin Kota Malang.

Waktu \& Tempat Kegiatan :

Hari / Tanggal : Rabu, 17 Pebruari 2016

J a m : $08.00-15.00$ wib.

Tempat : Ruang Pusat Pertemuan Ilmiah Kantor Pusat UNMER Malang Lantai III

Narasumber :

1. Prof. Ir. Agus Suprapto, M.Sc., Ph.D. (Korwil Posdaya JATIM II)

2. Ir. Hery Budiyanto, MSA., Ph.D. (Ketua Asosiasi Perajin Kota Malang)

3. Dyah Rachmalita, SE., M.AB. (UMKM Lita Glasspainting)

4. Faishal Arifin, SE. (Pemuda Pelopor Nasional ASTRA Award)

5. Erlin Sulistyawati (Posdaya Berprestasi Lumbung Arta Jaya)

6. Ide Bagus Weda

(Tim Kewirausahaan JTI Unmer Malang)

Peserta :

Sebagai peserta dalam kegiatan Seminar Kewirausahaan ini adalah 101 orang Guru Pengampu Mata Pelajaran Kewirausahaan SMK Kota Malang, Kab. Malang dan Kota Batu, 20 orang Ketua LPPM Perguruan Tinggi Kota Malang, 15 orang perajin yang tergabung dalam wadah APKM serta 15 orang Tim Kewirausahaan dari Jurusan Teknik Industri Universitas Merdeka Malang.

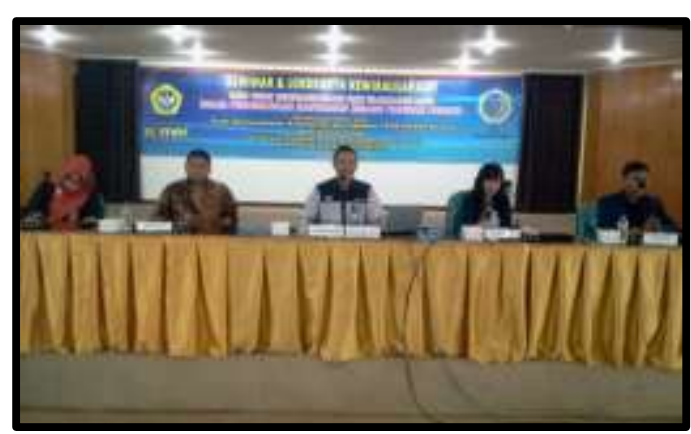

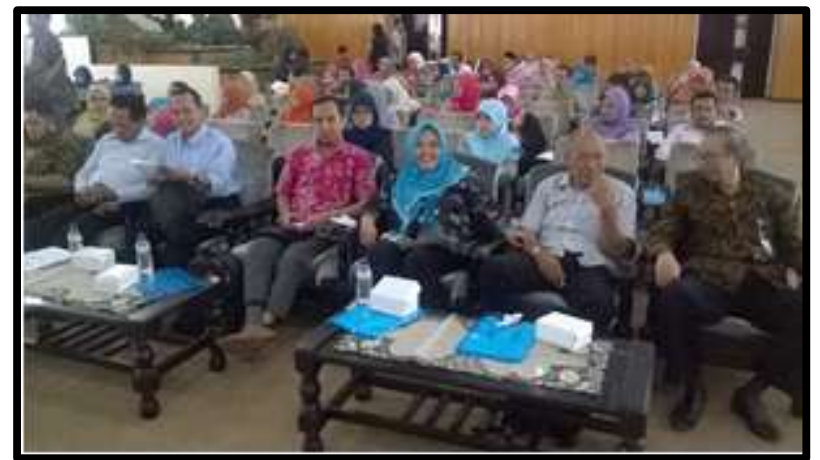
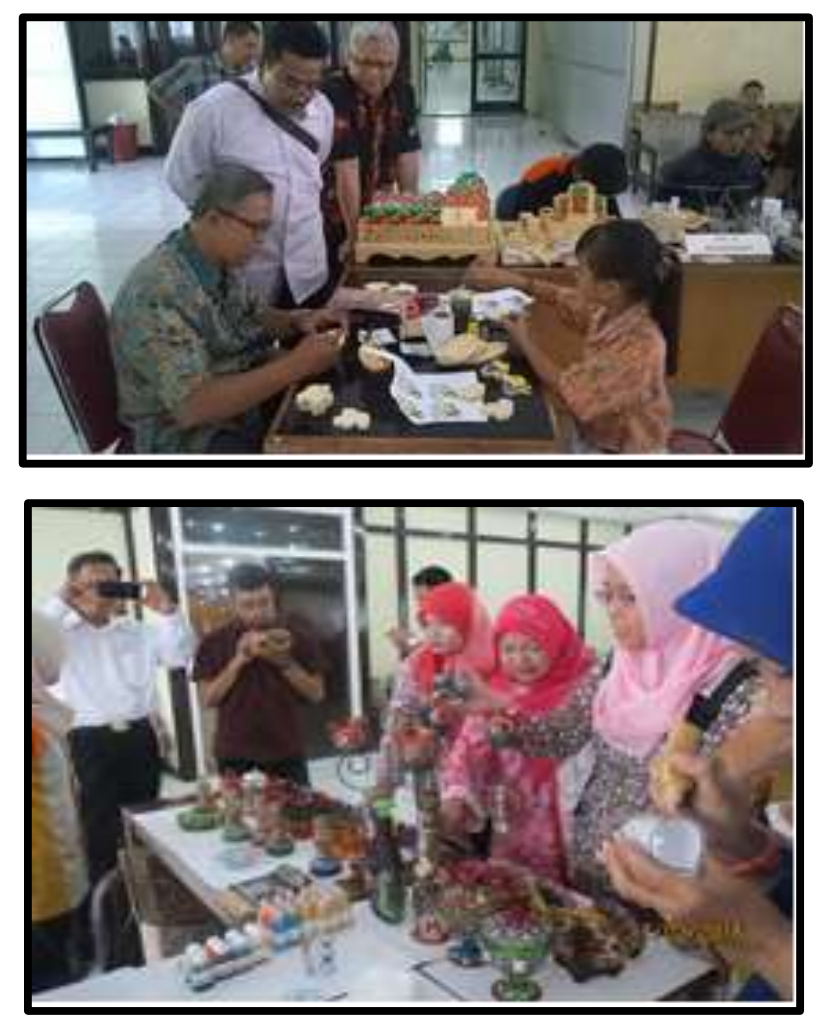

Malang City Expo 2017

Hari / Tanggal : Kamis - Minggu, 27 - 30 April 2017

J a m : $08.00-20.00 \mathrm{wib}$

Tempat : Stadion Luar Gajayana Malang

Acara : Mengikuti Malang City Expo 2017 yang diselenggarakan oleh Pemerintah

Kota Malang

Publikasi : Media Sosial

Peserta $\quad$ : 2 (dua) orang mahasiswa peserta

Program Inkubator Bisnis

1. Amanda Paramytha (FEB Manajemen)

2. Muhamad Nur Hafid (D3 Manajemen Informatika) 

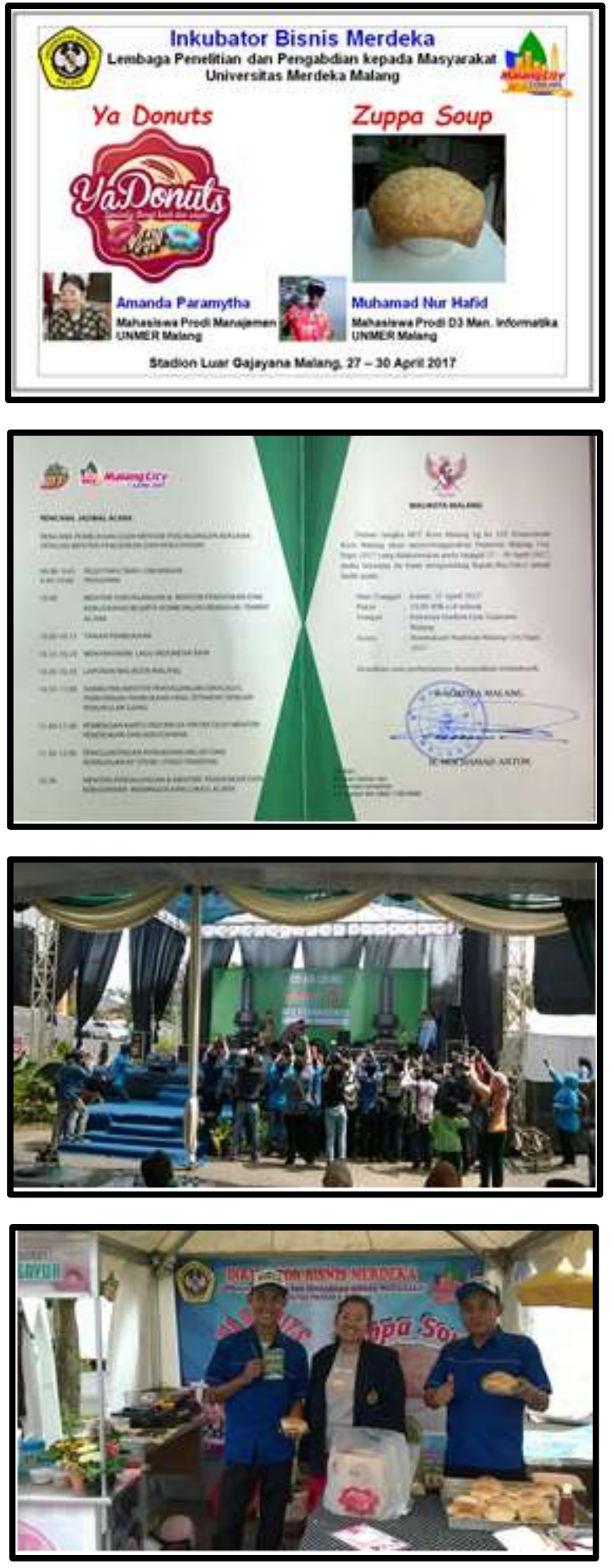

\section{Kuliah Tamu Entrepreneurship}

Universitas Merdeka Malang adalah Perguruan Tinggi yang sangat konsisten menjadikan Kemandirian dan Kewirausahaan sebagai Pola Ilmiah Pokok dalam proses belajar mengajarnya. Hal ini juga sejalan dengan Visi Perguruan Tinggi ini : "Menjadi Pusat Pengembangan IPTEKS, Kewirausahaan dan Pengembangan Sumberdaya
Manusia yang Berkualitas, Profesional, Kompetitif, Mandiri dan Berjiwa Wirausaha, Beriman dan Bertaqwa kepada Tuhan Yang Maha Esa".

Sebagai salah satu upaya guna mewujudkan ciri khas Universitas Merdeka Malang sebagai tempat pembentukan Sarjana yang sujana dan Sarjana yang mandiri sesuai dengan Pola Ilmiah Pokok tersebut, Lembaga Penelitian dan Pengabdian kepada Masyarakat (LPPM) Universitas Merdeka Malang melalui Pusat Kewirausahaan, Kemandirian dan Inkubatornya menyelenggarakan Kuliah Tamu dengan tema : "Peran Perguruan Tinggi dalam Pengembangan Entrepreneur melalui Program Posdaya", tepatnya pada hari Rabu kemarin tanggal 17 Mei 2017 jam 08.00 - 11.30 wib. bertempat di Ruang Pusat Pertemuan Ilmiah Kampus UNMER.

Prof. Ir. H. Agus Suprapto, M.Sc., Ph.D. sebagai Ketua LPPM mengatakan bahwa Kuliah Tamu ini diselenggarakan untuk menumbuhkan semangat dan rasa memiliki segenap warga civitas akademika UNMER Malang bersama stakeholder dalam menggerakkan program Kemandirian dan Kewirausahaan, salah satunya dengan mensinergikan Program Pengembangan Kewirausahaan LPPM dengan Program Pos Pemberdayaan Keluarga (POSDAYA).

Kuliah Tamu ini diikuti 200 orang yang terdiri atas Pengurus Posdaya Wilayah Jawa Timur II, Dosen Pendamping dari LPPM Perguruan Tinggi Negeri dan Swasta di Kota Malang serta mahasiswa UNMER yang menempuh Mata Kuliah Kemandirian dan Kewirausahaan di semester ini, dengan narasumber Prof. Dr. Haryono Suyono dari Jakarta. Beliau adalah mantan Menteri Koordinator Bidang Kesejahteraan Rakyat dan Kepala Badan Koordinasi Keluarga Berencana Nasional (BKKBN), yang menjadi inisiator dan penggerak program Pos Pemberdayaan Keluarga (POSDAYA) di Indonesia.

"Dengan kehadiran Profesor Haryono Suyono di Kota Malang ini, kami ingin menyegarkan kembali peran Perguruan Tinggi dalam pengembangan Entrepreneur dan pemberdayaan masyarakat, sekaligus memperkuat tali silaturrahmi di antara para penggerak Program Posdaya di kota ini”, kata pria yang akrab dipanggil Prof. Agus, yang juga sebagai dosen di Program Studi Teknik Mesin UNMER Malang ini. 
Dalam pelaksanaan Kuliah Tamu ini para undangan juga dihibur dengan penampilan " $i$ kustik", group musik akustik dosen dan mahasiswa Program Studi Teknik Industri UNMER, dengan arranger Aang Fajar Passa, SE., MMI. dan vokalis Mochammad Rofieq, S.Si., MT. Mereka membawakan 10 buah lagu karya legenda musik Indonesia Iwan Fals.

"Selain Kuliah Tamu ini, Pusat Kewirausahaan LPPM juga memiliki program kerja yang direalisasikan dalam bentuk aktifitas Diklat, Workshop Kurikulum, Inkubator Bisnis, Program Ipteks bagi Kewirausahaan (IbK) yang tahun ini lolos Dikti Tahun ke-II, Lomba Pembuatan Business Plan, Expo di luar kampus, Entrepreneur Day dan Entrepreneur Award yang akan dilaksanakan sekalian menyambut Dies Natalis UNMER Malang pada bulan Juli yang akan datang.", pungkas Profesor Agus.
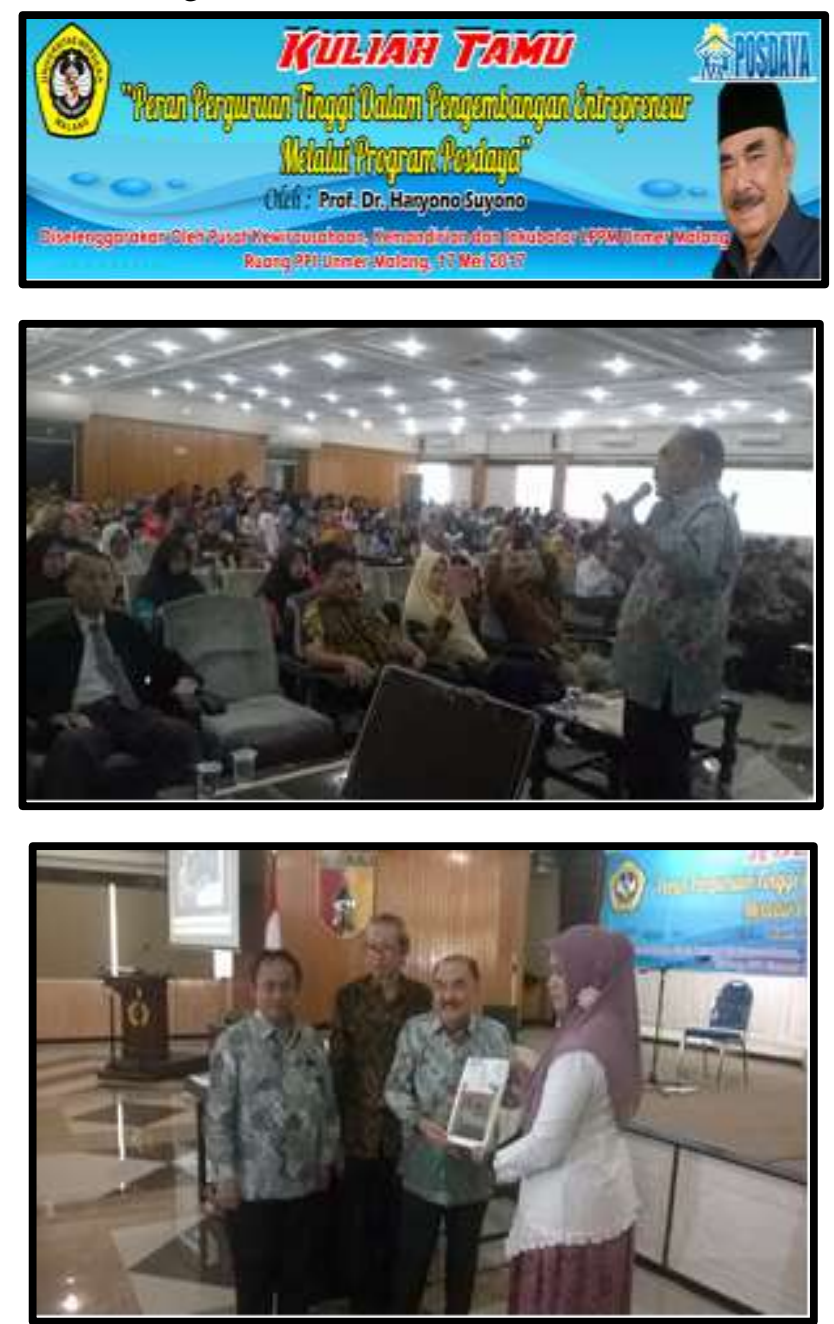

\section{Pelatihan Desain Kemasan Produk}

Hari / Tanggal : Selasa - Rabu, 1 - 2 Agustus 2017

J a m : $08.00-12.00$ wib.

Tempat $\quad: 1$. Ruang Rapat LPPM : Materi

Pembuatan Desain Kemasan

2. UMKM Sokressh Polowijen :

Praktek Pembuatan Kemasan

Instruktur $\quad:$ 1. Materi Desain Maulid Agung Triyono dan tim

2. Materi Praktek

Ir. Kristiawan

Peserta : 1. Posdaya

a. Asli : Kel. Pandanwangi, Kec. Blimbing, Kota Malang

b. Anggrek : Kel. Karangbesuki, Kec. Sukun, Kota Malang

c. Taman Rajut : Kel.

Kedungkandang, Kota Malang

d. Senang Hati : Ds.

Arjowilangun Kec. Kalipare

Kab. Malang

2. Asosiasi Perajin Kota Malang

3. AKU Kuliner Indonesia Kota Malang
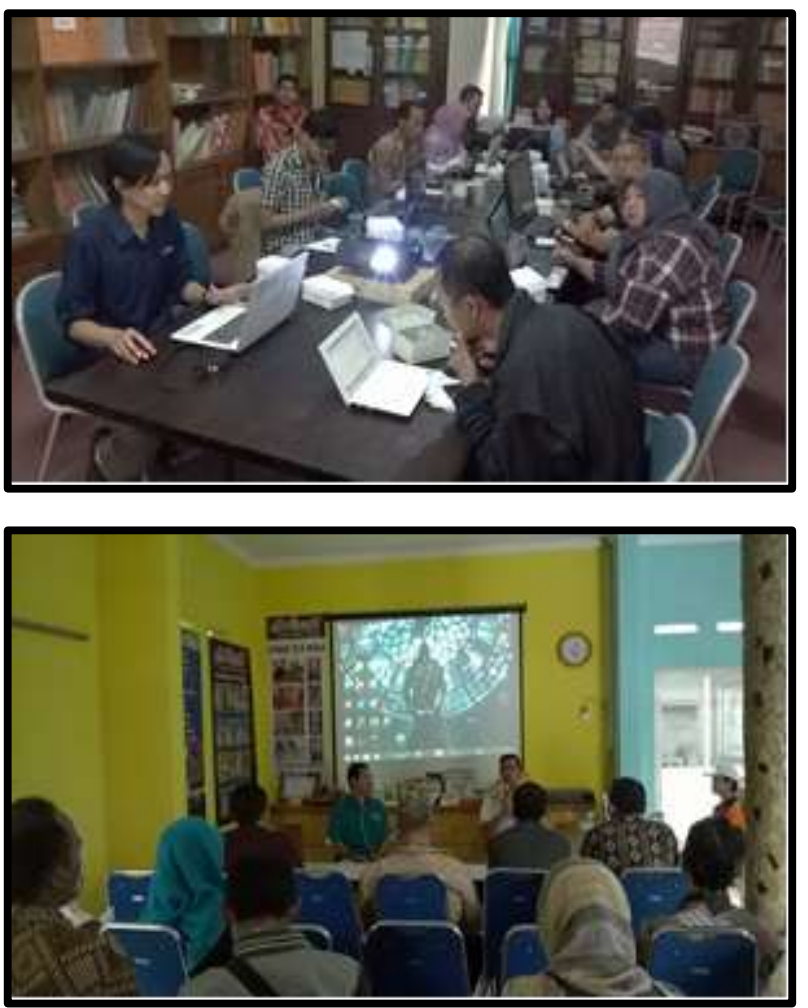

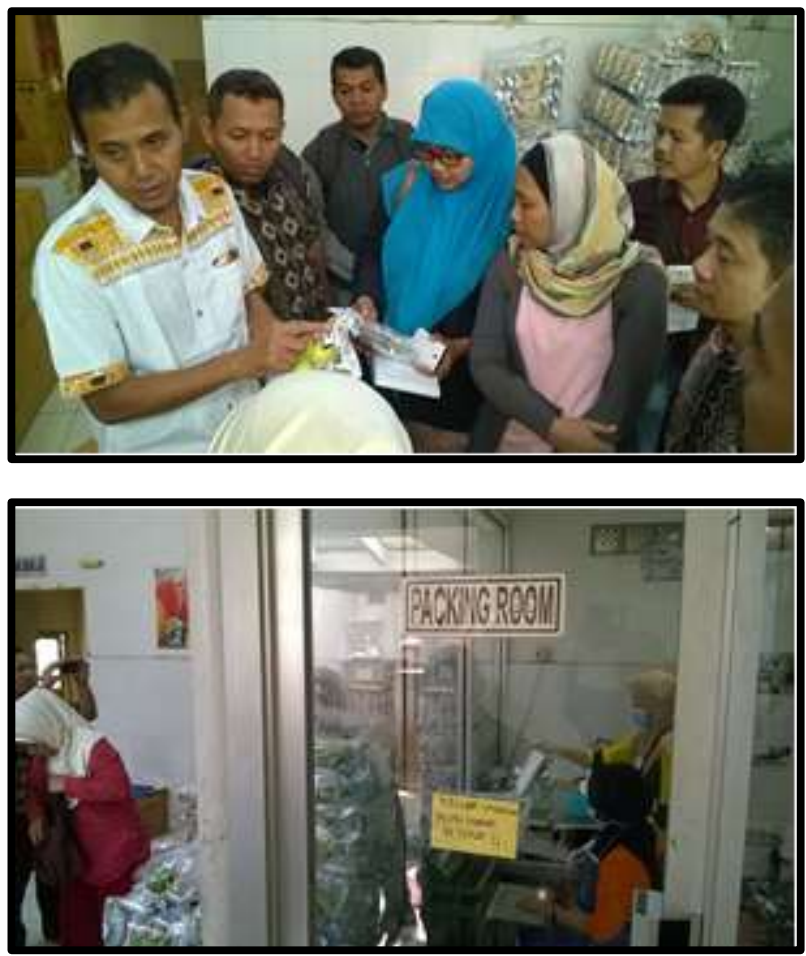

Pelatihan Kerajinan Lukis \& Pemanfaatan Botol Plastik

Hari / Tanggal : Sabtu, 25 Nopember 2017

J a m $\quad: 08.00-15.00$ wib.

Tempat : Ruang Inkubator LPPM Unmer Malang

Acara : Pelatihan Pembuatan Kerajinan

Lukis dan Pemanfaatan Botol

Plastik bagi mahasiswa baru

peserta Program Inkubator Bisnis 2017

Instruktur : Moses Joko Prasetyo

Mahasiswa Teknik Industri,

Peserta Inkubator Angkatan I

Pemenang Lomba Produk

Kerajinan Posdaya Wilayah Jawa

Timur II

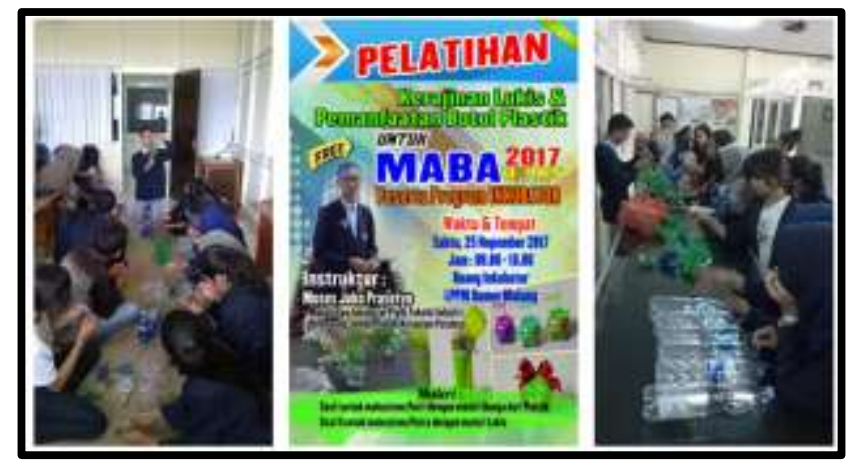

Pelatihan Praktis Packaging Berbasis Corel Draw

Hari / Tanggal : Rabu, 20 Desember 2017

J a m : $08.00-15.00$ wib.

Tempat : Ruang Laboratorium Komputer Lantai III Fakultas Teknologi Informasi Unmer Malang

Acara : Pelatihan Praktis "Packaging Berbasis Corel Draw"

Kerjasama LPPM dengan FTI AKU Kuliner Indonesia - Posdaya

Instruktur $\quad:$ 1. Ir. Heris Pamuntjar, MT.

2. Ir. Haris Satriawan, MM.

Peserta $\quad: 30$ orang yang terdiri dari mahasiswa peserta Program Inkubator Bisnis, pelaku usaha UMKM Bidang Kuliner, Posdaya Binaan LPPM dan Bapak / Ibu Dosen Jurusan Teknik Industri UNMER.

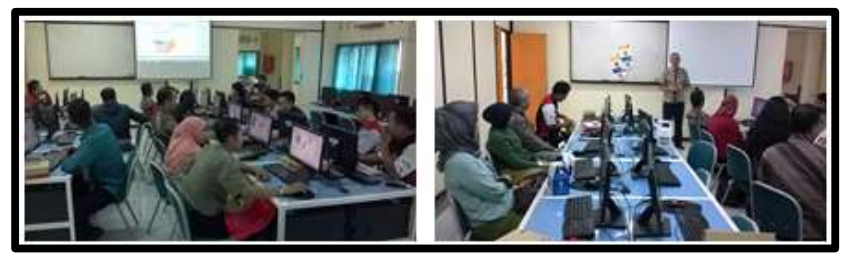

\section{Pelatihan Program Strive}

(Strengthening and Improving the Vibrant

\section{Entrepreneural Ecosystem)}

Hari / Tanggal : Sabtu, 27 Januari 2018

J a m : $: 09.00-12.00$ wib.

Tempat : Gedung Fakultas Teknik Lantai III Ruang 12 Unmer Malang

Acara : Pelatihan Pengelolaan Keuangan melalui Program Strive Strengthening and Improving the Vibrant Entrepreneural Ecosystem kerjasama Pusat Kewirausahaan LPPM dengan LPK Unmer Malang

Narasumber : Mochammad Rofieq, S.Si., MT. Ka. Pusat Kewirausahaan dan Inkubator LPPM Unmer Malang

Peserta : 30 orang yang terdiri atas mahasiswa peserta Program Inkubator Prodi Adm. Bisnis, UMKM Kuliner dan Posdaya Kota Malang. 


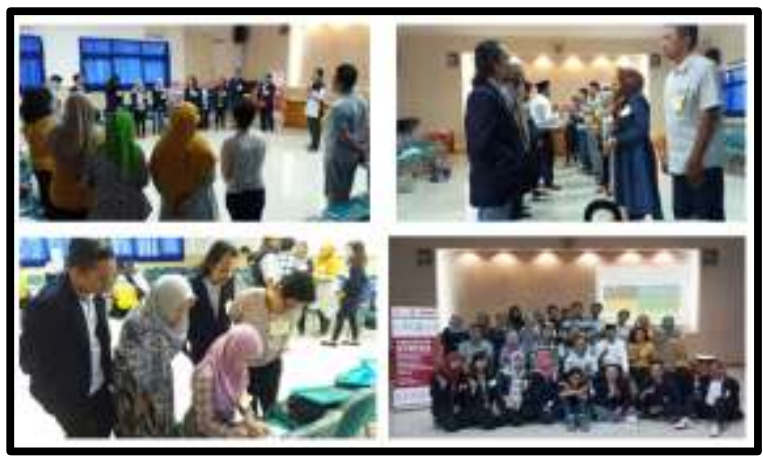

Focus Group Discussion LPPM - D3 Akuntansi -

$A K U-A P K M$

Hari / Tanggal : Rabu, 14 Pebruari 2018

J a m : $09.30-11.30$ wib.

Tempat : Ruang Rapat LPPM Kantor Pusat

LT III

Peserta $\quad: 1$. Ka. Program Diploma III

Akuntansi

2. Dosen Pendamping

3. Ka. Pusat Kewirausahaan LPPM

4. Asosiasi Perajin Kota Malang (2 UMKM)

5. Asosiasi Kuliner Indonesia (8

\section{UMKM)}

Tindak Lanjut : Pendampingan Akuntansi mahasiswa

Program Diploma III Akuntansi di UMKM Kerajinan dan Kuliner Kota Malang, dalam hal : Pencatatan Keuangan, Sistem Akuntansi dan Penyusunan Laporan pajak.
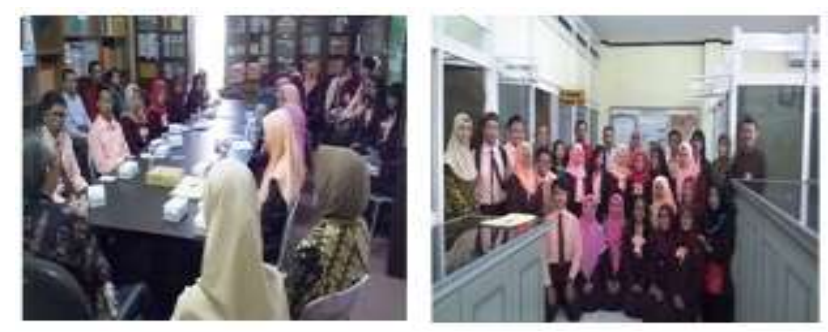

\section{Lokakarya Pendampingan Ibu Rumah Tangga}

\section{Pelaku UMKM}

Hari / Tanggal : Selasa - Rabu, 24-25 April 2018

J a m : Selasa $(09.00-20.00 \mathrm{wib})$; Rabu (09.00 - 15.00 wib).

Tempat $\quad$ : Ruang PPI Pendampingan Ibu
Rumah Tangga Pelaku UMKM

Kerjasama : Kinerja Hijau

Lantai III dan Halaman Kantor Pusat UNMER

Acara : Lokakarya

Pemateri : a. Bapak Faishal Arifin, SE. Asosiasi Perajin Kota Malang

b. Bapak Dody Triawan, ST. Asosiasi Kuliner Indonesia

Peserta : Sekitar 140 orang ibu rumah tangga pelaku UMKM dari Kab. Malang, Kab. Pasuruan dan Kab. Mojokerto; mahasiswa Program Inkubator Bisnis dari Prodi Manajemen, Teknik Industri, Psikologi, Administrasi Bisnis dan Komunikasi; serta Posdaya Asli Pandanwangi, Posdaya Taman Rajut Kedungkandang dan Posdaya Lumbung Arta Karangploso.
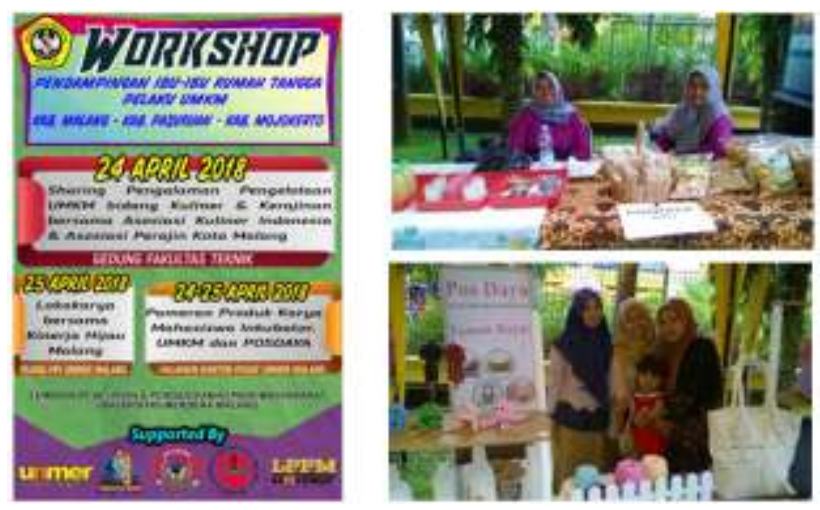

\section{TOT Pembiayaan UMKM Berbasis Syariah}

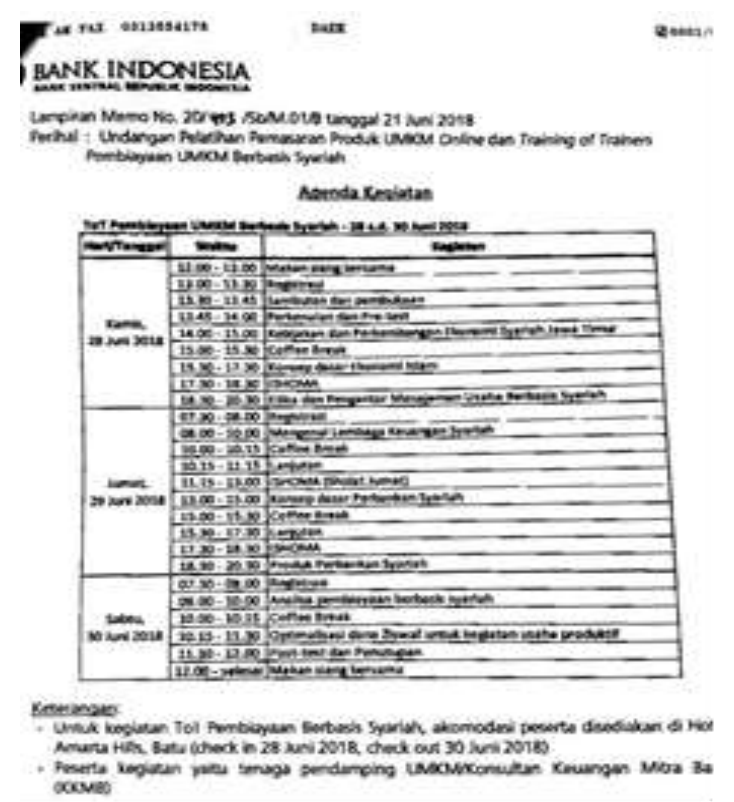



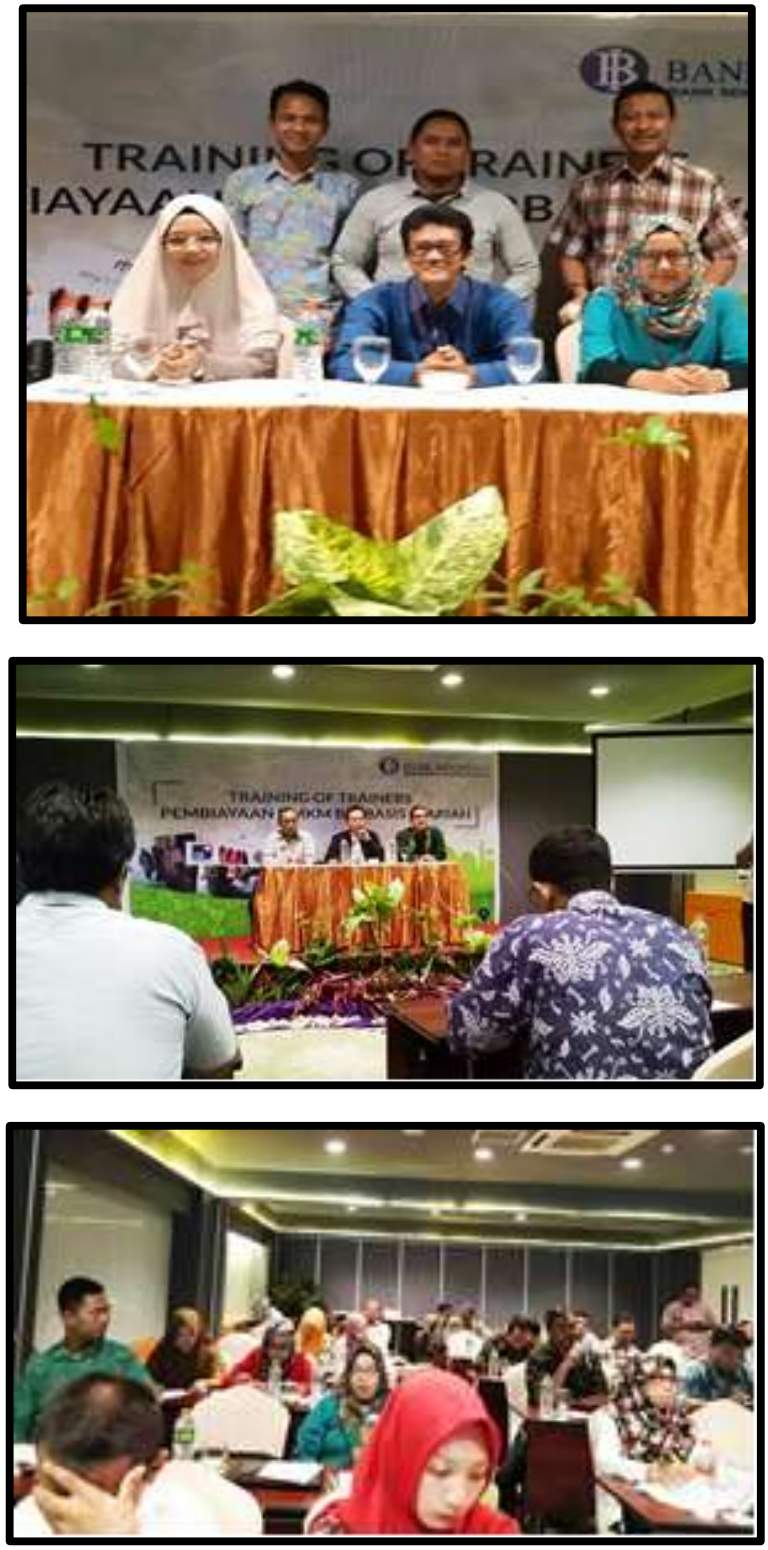

Model Pendampingan UMKM

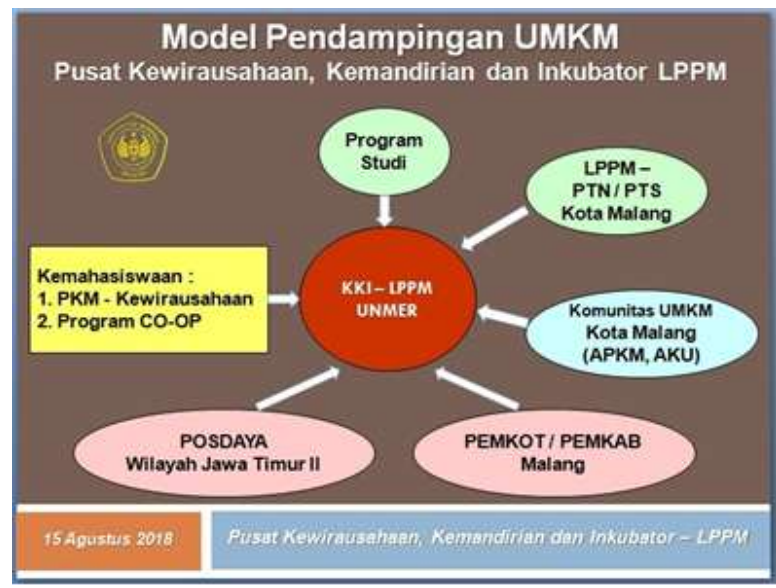

Gambar 1 :

Model Sinergi dalam Pendampingan UMKM (Sumber : LPPM Universitas Merdeka Malang)

\section{KESIMPULAN DAN SARAN}

\section{a. Kesimpulan}

Sinergi kerjasama antara Lembaga Penelitian dan Pengabdian kepada Masyarakat (LPPM) Universitas Merdeka Malang dengan berbagai komponen masyarakat, salah satunya Asosiasi Perajin Kota Malang (APKM) dalam pelaksanaan pendampingan UMKM telah memberikan dampak yang positif, karena melalui aktifitas ini Akademisi Perguruan Tinggi dan Praktisi UMKM dapat berinteraksi dalam memberikan tambahan keterampilan dan kesejahteraan bagi masyarakat.

\section{b. Saran}

Sinergi dari berbagai komponen masyarakat seperti ini hendaknya dapat dilanjutkan dalam bentuk pelatihan-pelatihan yang sistematis, karena melalui kerjasama ini Perguruan Tinggi turut aktif mengembangkan program kewirausahaan bagi Usaha Mikro, Kecil dan Menengah (UMKM) dan masyarakat luas pada umumnya.

\section{REFERENSI}

Budiyanto, H., Rofieq, M. (2016). Menumbuhkembangkan Wirausaha Mahasiswa dan Alumni Melalui Program Ipteks bagi Kewirausahaan di Universitas Merdeka Malang. Jurnal ABDIMAS Volume 1 Nomor 1 Desember 2016, LPPM Universitas Merdeka Malang.

Rofieq, M., Sugianto, Suprapto, A. (2013). Perancangan Stasiun Kerja yang Ergonomis Guna Meningkatkan Produktivitas Pembuatan Souvenir Berbahan Limbah Lampu TL. Prosiding Seminar Nasional Manajemen Teknologi XIX, ITS Surabaya.

Rofieq, M., Hariyanto, S., Wiati, N.M. (2014). Penerapan Metode Kansei Engineering guna Mengidentifikasi Atribut Desain dalam Perancangan Souvenir Khas Malang. Prosiding Simposium Rekayasa Aplikasi Perancangan dan Industri RAPI XIII, Univ. Muhammadiyah Surakarta.

Rofieq, M., Suprapto, A., Prilaswanti, D. (2015). IbM Usaha Kerajinan Perhiasan Perak Guna Menumbuhkan Minat Berwirausaha Bagi Karang Taruna Kelurahan Tanjungrejo. Prosiding Seminar Nasional Manajemen Teknologi XXIII, ITS Surabaya.

Rofieq, M., Purnomo, M.N., Permatasari, D., Farida, L., Hanafi, I., Fauzi, R. (2018). TOT KKMB Pembiayaan UMKM Berbasis Syariah. Bank Indonesia Jawa Timur.

Ulrich, Karl T., Eppinger, Steven D. (2001). Perancangan \& Pengembangan Produk. Penerbit Salemba Teknika, Jakarta. 